\title{
Nooreestlastest ja rahvaluulest
}

\begin{abstract}
Ruth Mirov
Teesid: Artiklis vaadeldakse Noor-Eesti nelja keskse kirjamehe - Gustav Suitsu, Johannes Aaviku, Villem Grünthal-Ridala ja Friedebert Tuglase - tegevust seoses rahvaluule, eriti regilauluga. Tutvustatakse vastavaid kirjatöid: artikleid, tekstivalimikke, õpikuid, kirjanduslugusid jms, samuti regilaulul põhinevat kirjanduslikku loomingut. Kuna eelmise sajandi alguskümnenditel päevakorda kerkinud Kalevipoja-kriitikas osalesid ka kõnealused nooreestlased, esitatakse artiklis nende arvamusi ja katseid eepost ümbervärsistada reeglistatud regivärsivormis.

Märksõnad: Johannes Aavik, Villem Grünthal-Ridala, Gustav Suits, Friedebert Tuglas, Noor-Eesti, Kalevipoeg, kirjanduse ja rahvaluule suhted, regilaul
\end{abstract}

Tartus ilmuva humanitaarajakirja Methis esinumbri paaris artiklis esines kummastavaid mõtteid nooreestlaste suhtumisest rahvaluulesse. Jüri Kivimäe oma üldiselt väga huvitavas ja sisukas artiklis kirjutab järgmist: "Nooreestlaste ebalevas, paiguti põlastavas hoiakus eesti rahvakultuuri, sealhulgas ka rahvaluulesse, tuleb näha ajastule omaseid suundumisi, mis väärtustasid vaid individuaalset kultuurilist loomingut kui intellektuaalset tegevust või kultuuri osa, pidades kollektiivset rahvakultuuri sageli alaväärtuslikuks" (Kivimäe 2008: 37). Tiit Hennoste ütleb samuti otsesõnu: "Nooreestlaste lähtekohaks oli omakultuuri ja rahvaluule primitiivsuse, puudulikkuse idee" (Hennoste 2008: 270). Viimatiöeldu on küll joonealuses märkuses, aga sama mõte on üheks lõppjärelduse eelduseks. Need ütlemised jäid painama. Noor-Eestit on ju lõpmata palju käsitletud ja siin-seal räägitud ka seostest rahvaluulega, kuid see on jäänud põgusaks kõrvalteemaks. Eeltoodud arvamuste kujunemisele on võib-olla kaasa aidanud ühe allikteosena kasutatud Oskar Looritsa artikkel "Nelja sugupõlve saatustragöödia", kus ta rahvuslikest muremõtetest haaratuna on nooreestlaste kohta öelnud muuhulgas järgmist: "Hõlpus oli mõnitada vana Hurda - Eiseni - Kalda harrastatavat rahvakultuuri "pastlakultuuriks" ja visata sellisena halvakspanevalt varna, kuid "Prantsuse buduaari" järgi- 
ahvimisega ei jõutud siiski veel meie balti provintsliku ersatz-kultuuri üldpilti asendada sügavama eestilise värvinguga" (Loorits 1955: 121). Rahvakultuuri võib ju värvikalt pastlakultuuriks nimetada, aga kahju küll, kui Looritsa ütlemine vääradele jälgedele juhatab. Ütlemistega on nagu on: mõnel neist on püsivamat tõeväärtust, mõnel on mingit tähtsust ainult omas ajahetkes ja kontekstis, kuid siiski annavad mingi ajajärgu kaasaegsete mõtteavaldused parimat teavet sellest ajast. Peamiselt ammustele mõtteavaldustele püütakse ka käesolevas arutluses tugineda.

Artikli põhiosas vaatlen nelja keskse Noor-Eesti kirjamehe - Gustav Suitsu, Friedebert Tuglase, Johannes Aaviku ja Villem Grünthal-Ridala - tegelikke tegemisi rahvaluule vallas, keskendudes sealjuures regilaulule. Tundub, et selline kokkuvõtlik ülevaade on vajalik hoolimata varem ilmunud üksikkäsitlustest. Need on siin-seal hajali ja terviklikum pilt on puudu, kuigi detailid tunduvad tuttavad.

\section{Mõned taustamärkmed}

Noor-Eesti algusajal kestis veel 19. sajandi viimastel kümnenditel ägestunud venestamine. Eesti rahvas ja keel olid nagunii sajandeid olnud tõrjutud, nüüd aga oli tegu sihikindla väljasuretamisega. Johannes Aavik on kirjutanud oma gümnaasiumi-aegses päevikus, et eesti rahva võib päästa vaid täielik autonoo-

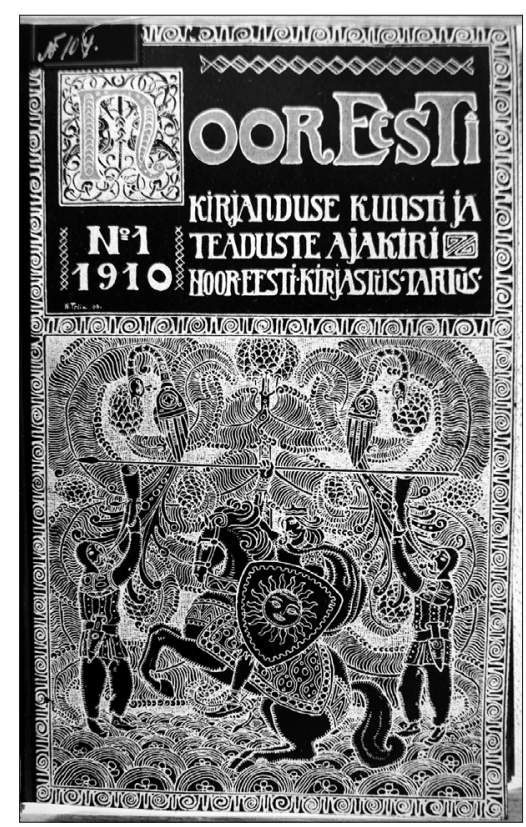

mia. Ta lisab, et kuigi saksa meel ja mõju on mingil määral murtud, tuleb veel koledama kolli - vene vaimu, võimu ja valitsuse vastu võitlema hakata. Noore Aaviku meelest on olukord mõistetamatu: üksiku indiviidi tapmine on küll keelatud, terve rahvuse ärakaotamine aga lubatud! ${ }^{1}$

Rahvusluse teemal arutledes on selge, et vaieldamatult suured rahvuslased olid Johannes Aavik ja Villem Grünthal, olid seda juba õpinguajal Kuressaare gümnaasiumis, ja jäid selleks elu lõpuni.

Kuid ka Friedebert Tuglase mitmest kirjutisest selgub, et Noor-Eesti rahvuslike tõekspidamiste kinnitamine on talle tähtis

Foto 1. Ajakiri Noor Eesti 1910 nr 1, kaas Nikolai Triik. Foto: EKLA, 9X37: 3678. 
ning mitmesugustel põhjustel muutus ajapikku aina tähtsamaks. Veel aastaid hiljem õiendab ta omaaegsete kritiseerijatega: "Oleks põhjust veel lähemalt peatuda ajastul, mil "eurooplaseks saamine" otse programmina päevakorrale tõsteti. See liikumine ei olenenud igatahes mitte algatajate eneste rahvustunde nõrkusest, nagu arvasid senises rahvusmõistes kinni rippuvad arvustajad, vaid just meie tolleaegse rahvusliku elu ilmetuse, jõuetuse ja iseseisvusetuse äratundmisest. Meie ühiskondlik kultuuritase, kunstimaitse, keeleareng oli taha jäänud, meie kirjandus ainult kahe naaberrahva - saksa ja vene - mõju all, mida läheduse tõttu enam ei nähtudki. Siin võisid aidata ainult mõjud laiemast maailmast, mis oleksid äratanud võrdluse, võistluse, teadliku valiku vaimu. Tuli avardada meie rahvusmõistet täisealisusele läheneva kultuurrahva nõuete kohaselt" (Tuglas 2001: 283).

Jüri Kivimäe avaldab eespoolmainitud artiklis imestust: "Kummastav on vana talupojakultuuri (või siis eesti rahvakultuuri) euroopaliku kultuuriga kõrvutamise sobimatuks pidamine, sest ka nooreestlaste enamik pärines külaühiskonnast, linlased oldi alles esimest põlve" (Kivimäe 2008: 38). Otsest viidet toodud pole, kuid arvatavalt on väite aluseks Tuglase artikkel "Kirjanduslik stiil”. Euroopaliku kultuuri all on ilmselt mõeldud tollast haritlaste kirjakultuuri, sellega meie rahvakultuuri kõrvutamine ongi tegelikult mõttetu; võrrelda tuleks ikka võrreldavaid, sama tasandi nähtusi, ehk siis meie rahvakultuuri teiste Euroopa maade rahvakultuuriga, aga sellega olime igati tasemel. Leidis ju Jakob Hurda rahvaluule-alane tegevuski erialateadlaste tunnustuse juba 19. sajandi lõpul. Tegelikult olime meie tollases Euroopas oma talupojaseisusest hoolimata päris kultuurne rahvas, ka kirjakultuuri mõttes: "19. sajandi lõpuks saavutasid üleüldise kirjaoskuse Saksamaa, Šotimaa, Rootsi, Soome, Inglismaa, Eesti; Prantsusmaal oli kirjaoskajaid 83\%, Itaalias 52\% ja Venemaal 28\%" (Aarma 1990: tsiteeritud lause on sisu kokkuvõttena raamatu kaanel).

Tuglas taotles ikka kõrgkirjandust, kõrgkultuuri, ja sellega oli meil muidugi raskusi, kuna väga vähe oli omast rahvusest kõrgharitlasigi. Ja veel 19. sajandi lõpul need vähesed, kes olid natuke rohkem haridust saanud, vahetasid tihtipeale rahvust. See on Jakob Hurda ärkamisaegsetes sõnavõtmistes üks põhilisi mureküsimusi, ja sama mure kestis edasi aastaid pärast ärkamisaega. Aavik kõneleb sel teemal veel 1914. aastal ilmunud artiklis (Aavik 1988). Kuigi Noor-Eesti sünniajal oli eestlasest kõrgharitlasi alles vähe, oli rahva üldine haridustase siiski nii kõrge, et sajandivahetusel ja 20. sajandi alguse muutlikel aegadel toimus eestlaste ja eestluse kiire esiletõus, nii majanduslikus kui ka kultuurilises mõttes.

Üks eestimeelsete kokkusaamiskoht Tartus oli Jaan Tõnissoni Postimehe toimetus. Sellesse nn Postimehe ringkonda kuulusid ka Aino ja Oskar Kallas, viimane oli sõna otseses mõttes Tõnissoni parem käsi. Ka oli Kallaste kodu 
avatud ärksatele noortele. Need kolm isikut - Jaan Tõnisson, Aino ja Oskar Kallas - olid peamised, kelle abil ja õhutusel siirdus noori Soome vabamatesse oludesse, õppima Helsingi ülikoolis rahvusteadusi. Nii läksid sinna aastatel 1905-1906 ka nooreestlased Gustav Suits, Villem Grünthal ja Johannes Aavik. Suits oli juba mõni aasta olnud Postimehe kaastööline. Samuti töötas Tuglas pärast Linnakooli lõpetamist aastakese (1903-1904) selle ajalehe juures. Ka hiljem tegid kõnealused nooreestlased Postimehele kaastööd (Suits, kes 1913. aastal teravalt Tõnissoni vastu pöördus, veel aastani 1912), või koguni töötasid toimetuses nagu Aavik aastatel 1912-1914 ja Tuglas aastatel 1917-1918, kui Tõnissonil omakorda tuli maapakku minna.

Tuglasel jäi revolutsioonilisest tegevusest aktiivse osavõtmise tõttu haridustee pooleli, aga 1906. aastal tuli temalgi siirduda Soome - pagulasena. Niisiis olid aasta 1906 sügiseks jõudnud Soome kõik neli tähtsamat nooreestlast, kolm neist üliõpilasena. Nende kõigi õppeainete hulka kuulus folkloristika. Siinkohal võiks ju ironiseerida - nooreestlased läksid õppima "pastlakultuuri”.

Aga miks siis ikkagi õppida folkloristikat? Tuleb meenutada, et 20. sajandi algul oli veel jõus Jakob Hurda poolt 1888. aastal algatatud rahvaluule suurkogumine, mis haaras kogujate, laulikute ja jutustajate näol tuhandeid inimesi ning oli venestusajal ainuke tõeliselt massiline rahvuslik ettevõtmine. Kogujate hulgas oli palju just maaharitlasi, nagu kooliõpetajaid. Hurt avaldas kogumistöö kohta aruandeid ajakirjanduses, ka Postimehes, millega levitas teadmist sellest aktsioonist veel laiemalt. Vaieldamatult oli kogumisaktsiooni tähtsus tohutu - sellega päästeti eesti rahva rikkalik, sadu aastaid vana suuline looming hävingust. Jakob Hurt, kes oli Eesti Üliõpilaste Seltsi auliige, haaras seltsi kaudu kogumistöösse ka üliõpilasi. Nii on üliõpilasena rahvaluulet kogunud Oskar Kallas, kes 1901. aastal kaitses Helsingi ülikoolis regilaulu-alast doktoritööd ja on meie esimene rahvaluuledoktor. 1904. aastal algatas Oskar Kallas rahvaviiside kogumise Eesti Üliõpilaste Seltsi egiidi all, see aktsioon oli samuti ülemaaline, suuri hulki haarav ja tulemuslik ning kestis Esimese maailmasõja päevini. Kogujate hulgas oli palju muusikalist haridust saanud inimesi. Niisiis oli rahvaluule, eriti regilaul prestiižne ennekõike just rahvusmeelsete haritlaste hulgas nii maal kui ka linnas ja tunnustatud kui rahvusliku identiteedi üks tugisambaid. Rahvaluulel oli meie "kultuurihierarhias" kõrge asend juba ärkamisajal, kuna tänu Jakob Hurdale oli rahvaluule kogumine ka Eesti Kirjameeste Seltsi üks prioriteete. Seega oli rahvaluule ühiskonna teadvuses tähtsana püsinud juba mitukümmend aastat. Möödunud sajandi algul ei vastandunud rahvaluule ja sellega tegelemine küll kuidagi kõrgkultuurile, vaid oli pigem selle osa. Rahvaluule "reiting" oli kõrge ka meie tollases esmases ihaldusmaas Soomes, seda enam, et Soome folklooril ja folkloristikal oli siis maailmale paljugi öelda: olid väärtuslikud rahvalaulud ning üldtunnustatud 
kangelaseepos Kalevala, ning oli Julius ja Kaarle Krohni loodud geograafilisajalooline meetod ( $\mathrm{nn}$ soome meetod), mis oli samuti laiemalt tuntud.

Meie folkloristika areng on olnud tihedalt seotud soome folkloristikaga, algul mõneti tugines sellele. Soome Kirjanduse Selts ja Helsingi ülikool ennekõike rahvaluuleprofessor Kaarle Krohni isikus aitasid kaasa Jakob Hurda rahvaluule kogumise aktsioonile; Soome Kirjanduse Selts (Kaarle Krohni eestvedamisel) kirjastas Jakob Hurda Setukeste laulud ning kandis trükikulud. Kaarle Krohn oli ka Matthias Johann Eiseni sõber ja rahvaluule-alase tegevuse toetaja, organiseeris ju Eisengi aastaid kestnud kogumistööd. Eespool oli juba juttu Oskar Kalda Helsingi ülikoolis kaitstud doktoritööst. Ka tema kogumismatku Lutsi ja Kraasna maarahva juurde ning kogutud materjalide trükkimist toetas Soome Kirjanduse Selts. Loetelusse võiks veel mõndagi lisada, kuid tagantjärele on kõige olulisemaks osutunud ehk see, et pärast Jakob Hurda surma võeti tema rahvaluulekogu Kaarle Krohni initsiatiivil mõneks aastaks hoiule Soome Kirjanduse Seltsis, kuna meil nii väärtusliku kogu säilitamiseks sobivat asutust siis veel polnud. 19. sajandi teisel poolel alguse saanud tihedad sidemed Soome folkloristidega jätkusid Eesti Vabariigi ajal lüroeepiliste regilaulude publitseerimisega: Eesti rahvalaulud Dr. Jakob Hurda ja teiste kogudest I-II (Tartu, Eesti Kirjanduse Selts 1926 ja 1932). Siinses artiklis huvi pakkuvatest isikutest võtsid sellest tööst osa Kaarle Krohn, Villem Grünthal ja nii Kaarle Krohni kui ka nooreestlastega lähedasi kontakte omav Oskar Kallas, kes oli siis küll Eesti Vabariigi saadik Inglismaal, kuid just tema on kirjutanud väljaandele südamlik-asjaliku saatesõna.

Mingisse rahvusse kuulumine, nagu Suitski omal ajal tõdes, on inimese loomulik seisund (Suits 1906: 51-55). Ja ega rahvuslanegi saa olla väga mitmel moel, põhimõttelised erinevused lähtuvad pigem ikka muudest poliitilistest vaadetest. Siinse kirjutise alguses tsiteeritud artiklis käsitab Tiit Hennoste nooreestlaste ideoloogilise palge ja kirjandusliku mõtteviisi esindajatena ainult Suitsu ja Tuglast ("osalt” J. Aavikut ja J. Semperit; arvestamata näiteks V. Ridala seisukohta, et iga rahva kirjandusel on paratamatult rahvuslik iseloom), järeldused on aga esitatud üldistatult nooreestlaste nimel. Artiklis on muuhulgas märgitud sedagi, et nooreestlased liikusid rahvuslusest sotsialismi. Ei tea, kas Aavikut või Ridalat saaks mingil moel siduda sotsialismiga?! Siinkohal maksab aga meenutada Aaviku kirjades korduvalt ilmnevat - erasuhted ja kirjanduslikud vaated tuleks poliitikast lahus hoida (Aavik 1990).

Paljudes asjades erimeelsete suurte isiksuste kokkukuulumine on ikka olnud probleemne. Noor-Eesti looja Gustav Suits on ise hiljem öelnud: "Ühistegevuse aktiivsemaski järgus pole Noor-Eesti koosseis ja eeskava kunagi olnud päris ühtlase ilmega. See koondis oli võimalik noorusliku intelligentsi valmimisprotsessis ja arusaadav esimese revolutsiooni tuultepöörisele järgnenud poliitilises 
õhkkonnas" (Suits 1931: 5). Siia juurde võib meenutada Tuglase ütlemist noore isiksuse enda ja maailma avastamisest ning nooruse suurtest sõnadest (Tuglas 1996a: 326-327). Ridala on omal ajal pidanud siduvaks sarnast tundmuse- ja vaimulaadi, ühist vaimset tasapinda (Ridala 1918: 82 ). Ühisest vaimsest tasapinnast räägib ka Aavik kirjades Tuglasele. Ja Aino Kallas märgib: "Kuid puht-kirjanduslikuna liikumisena pole Noor-Eesti ometi ligikaudugi ühtlane, homogeen nähtus" (Kallas 1921: 25). Ajakirja Methis sissejuhatavas artiklis ütlevad Sirje Olesk ja Marin Laak erinevuste kohta nii: "Nende tööd ja erakirjad tõestavad, et nii nagu erinesid nende elukäsitlused, oli erinev ka nende arusaam näiteks rahvuslusest, samuti muutusid aastate kuludes nende isiklikud vahekorrad.” Ning arutluse võtab kokku üldistus: “... võiks siiski nende peamiseks ühendajaks pidada rahulolematust eesti senise kirjanduse, keele ja vaimsusega" (Olesk \& Laak 2008: 7). Küllap see nii on. Aga kuhu ikkagi paigutub rahvaluule? Kus ja kuidas väljendub see ühine seisukoht, mis võimaldab öelda, et nooreestlastel oli põlastav hoiak rahvaluule suhtes?

\section{Tegemisi rahvaluule-vallas}

\section{Johannes Aavik}

Johannes Aavik lõpetas Helsingi ülikooli 1910. aastal cand. phil. kraadiga (atesteeriti filosoofiamagistri kraadiks 1920. aastal). Raamatus Noor-Eesti keskendub Aino Kallas kirjanduslikule loomingule ja räägib Aaviku puhul "Ruthist”, sissejuhatuses küll ka tema keeleuuenduslikust tegevusest. Mõte keele teadlikust parendamisest käis läbi juba Aaviku koolipoisi-päevikust, Noor-Eesti esimeses albumis avaldas ta artikli "Eesti kirjakeele täiendamise abinõudest". 1912. aastal võttis ta mitmel koosolekul sõna ka Kalevipoja keele kohta ning 1914. aastal avaldas poolesaja lehekülje paksuse raamatu Eesti rahvusliku suurteose keel (Aavik 1914). Raamatus on lisad: Rahvalaulu salmimõõt; Rahvalaulu keel; Proov parandatud "Kalevipoja” teksti. Niisiis tuli Aavik uurijana regilaulu juurde oma keelehuvi ja Kalevipoja kaudu. Sama "Keelelise uuenduse kirjastiku" egiidi all ilmus paari aasta pärast veelgi täielikum paranduskatse (Aavik 1916). Mõtted Kalevipoja parandamisest kutsusid esile poolt- ja vastuväiteid, viimatimainitud teoses on Aavik ise jõudnud arusaamisele, et vigadest hoolimata oleks parandamine mõttetu. Siiski ei muutunud tema seisukohad hiljemgi, hästi selgub see raamatust, mille ta on avaldanud ainult paar aastat enne eepose piduliku väljaande ilmumist raamatuaastal 1935. Aaviku raamat sisaldab eepose sisu ümberjutustuse ning keele, värsiehituse, stiili, kompositsiooni jms kriitilise analüüsi. Peaidee (võitlus põrgu ja sarvikuga ning raudmeestega) 


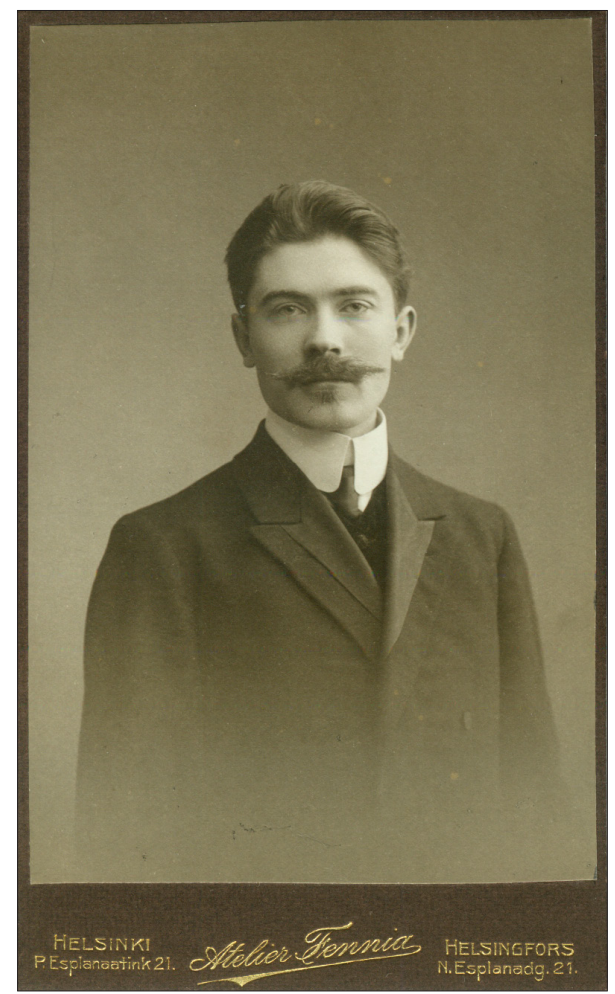

Foto 2. Johannes Aavik. Foto: EKLA, A160: 10.

kõrval märgib Aavik teise tähtsa motiivina saatuse paratamatut neima, mis on eepose üllaim idee ja oluline ka kompositsiooniliselt, kuna seob alguse ja lõpu. Neid märkusi võiks tõlgendada kui tunnustust Kreutzwaldi kirjanikutalendile, ometi on eeposele osaks saav kriitika veel karmim kui varasemates kirjutistes. Nüüd nimetab ta eesmärgiks objektiivsele tõele vastava hinnangu andmist, et ei jääks muljet, nagu oleks tegu kirjanduslikult väärtusliku teosega. Aaviku arvates on sellist väära muljet püüdnud jätta mõnedki eeposest kirjutajad, teiste hulgas ka Ridala (Aavik 1933).

Siinse artikli seisukohalt on aga oluline rõhutada, et eepose kriitiline lahkamine Aaviku poolt toimus pidevas võrdluses pärimusliku regilauluga, selle keele ja poeetilise võttestiku analüüsimine ning kirjeldamine tähendas üha põhjalikumat süvenemist regilaulu olemusse. Ühtlasi tõi selline menetlemine hästi esile regilaulu kunstiväärtuslikkuse ning sedakaudu selgus ka Aaviku kõrge hinnang regivärsilisele rahvalaulule. 
Eesti Vabariigi koidikul tekkis suur vajadus rahvaluulet, eriti muidugi regivärsilist rahvalaulu esitavate valimike (õpikute) järele, regilaulu tunnustati ju kui puhtaimat ja kauneimat omakultuuri väljendit. Aastatel 1918-1919 ilmus koguni viis regilauluvalimikku ning üks neist oli Aaviku koostatud (Aavik 1919). Aavik ise töötas siis juba mõnda aega õpetajana - 1914-1919 Tartus, alates 1919. aastast Kuressaares. Tema raamat on tähelepanuväärne juba selle poolest, et sisaldab kõiki regilauluantoloogiatele traditsiooniliseks kujunenud lisasid: Keel; Rahvalaulu värsiehitus ja stiil; Rahvalaulude autorid, ained ja iga; Ajaloolised teated rahvalaulude korjamisest; Sõnastik. Rahvalaulutekstid on liigitatud temaatilis-funktsionaalselt, nagu seegi tavaks on saanud. Raamatu teine trükk, kus on Lucie Põdrase täiendusi ja näiteid viisidest, ilmus 1935. aastal (Aavik 1935). Aaviku pagulaspõlves ilmus raamatust veel kolmas trükk (Aavik 1970). Selle aluseks on teine trükk, kuid Põdrase täiendused on välja jäetud. Teos on pühendatud Johannes Aavikule tema 90. sünnipäeva puhul ja seetõttu sisaldab Viktor Kõressaare juubelikirjutise. Kõressaar mainib mõningaid muid regilaulu-antoloogiaid ja kirjutab järgmist: "Ometi on Johannes Aaviku valimik nende kõrval ainulaadne ja originaalne seetõttu, et see on ikka veel ainus antoloogia, mis on koostatud esteetilisest ilukirjandusliku kunstimeisterlikkuse printsiibist lähtudes, kuna teistes antoloogiais valitseb tugeval määral pigemini etnograafiline printsiip" (Kõressaar 1970: 7). Niisiis redigeeris Aavik laulutekste: ta kõrvaldas üleskirjutustes leiduvaid keelelisi vigu ning ühtlasi kohendas värsivormilt "vigaseid" kirjapanekuid vastavaks ideaalmudelile, mille Kaarle Krohn on sõnastanud kalevalavärsiliste runode põhjal, kuid on kohandatav ka meie, eriti Põhja-Eesti, regilauludele.

Viktor Kõressaar lõpetab oma saatesõna järgmiselt: "See pidev ja sügavale tungiv tegelemine eesti regivärsiga on Johannes Aavikut sundinud ka iseseisvale loomingule regivärsi viljelejana. Käesoleva väljaande viimase luuletusena avaldataksegi esimest korda Johannes Randvere regivärsiline ballaad “Öö saladused", mille teema on ühine Fr. R. Kreutzwaldi muinasjutuga "Kuuvalgel vihtlejad neitsid"' (Kõressaar 1970: 9). Raamatust ei selgu, millal luuleteos on kirjutatud. Pole võimatu, et alles vanemas eas, inspireerituna August Annisti "Lauluema Marist”. Kuid see kinnitakski kestvat huvi regivärsi kui ürgomase ja stiilse luulevormi vastu.

Regilauluantoloogia kolme trükiga Aaviku regilauluväljaanded ei piirdu, kooli tarbeks on ta koos teiste autoritega andnud välja veel lugemiku Rahvalaule ja "Kalevala" keskkoolidele (Aavik jt 1935). Rahvalaulude osa on päris mahukas ning esindab kõiki regilaulu temaatilisi rühmi, lisaks on uuemaid rahvalaule, vanasõnu ja mõistatusi. Raamatus on ülevaated regilaulude keelest, värsiehitusest, stiilist, ainetest, laulikutest, kogujatest ja kogudest. Kalevala käsitlusele lisaks on ka mõni lause Kalevipojast: "Selle mõju oli umbes sama, 
mis "Kalevalalgi": tekkis rahvuslik iseteadvus ja käsitus ühisest isamaast, ärkas innukas rahvaluulekorjamine ja Eesti sai väljaspoolgi tuttavaks" (Aavik jt 1935: 201).

Enamasti samade autorite õpikus Eesti kirjanduslugu gümnaasiumile on räägitud Jakob Hurdast ja rahvaluulekogumisest, Hurda kogu on nimetatud maailma suurimaks. Nagu Aaviku eespoolmainitud artiklites ja raamatutes, nii on siingi käsitletud regilaulu värsiehitust, keelt ning laulude aineid ja loojaid (Aavik jt 1944a). Õpik sisaldab ka väikse valiku regilaule (lk 238-253) ning lisaks vanasõnu ja mõistatusi (lk 253-254). Sellest õpikust on Teise maailmasõja järel põgenikelaagris Geislingenis tehtud osaline väljaanne (Aavik jt 1944b), kus on öeldud, et kõigist sisulistest, kompositsioonilistest ja stiililistest puudustest hoolimata on Kalevipojal suur rahvuskultuuriline tähtsus ning eepos avas rahvusromantilise ajajärgu meie kirjanduses. Õpikus on juttu ka Jakob Hurda rahvaluulekogumisest ja regilaulu-väljaannetest. Geislingenis ilmus raamatust veel teine trükk ning on tehtud masinakirjas paljundusi (samuti osalisi), kus esineb regilaulutekste (Aavik jt 1947).

Aaviku regilaulu-alase tegevusega seoses tuleb kindlasti meenutada vaidlust Suitsuga regilaulude skandeerimise küsimuses, mille vallandas Aaviku õpetamis-metoodiline artikkel "Rahvaluule käsitlus keskkoolis" (Aavik 1924: 259-265). Ja vastusena Suitsule järgnes temalt artikkel "Rahvalauluvärsi ja selle lugemise küsimus” (Aavik 1925: 92-95). Nende artiklitega osutab Aavik veel kord, et ka eesti regilaulus kehtivad kvantiteedireeglid. Aaviku seisukohti on asjalikult valgustanud Taive Särg, kes ütleb, et kõrvutused ja võrdlused antiikluule ja kalevalavärsiga kajastavad Aaviku püüet väärtustada eesti kultuuri (Särg 2004: 93-113). Eks sama idee - väärtustada eesti kultuuri - kandis ka Kalevipoja parandamiskatseid. Nii oma keeleuuenduslikus kui ka regilaulualases tegevuses oli Aavik ennekõike rahvuslane ja esteet, neis kahes mõistes sisaldus talle nii lähtekoht kui ka eesmärk.

\section{Gustav Suits}

Gustav Suits lõpetas Helsingi ülikooli 1910. aastal cand. phil. kraadiga (magister 1919). Raamatus Noor-Eesti veab Aino Kallas paralleele Suitsu noorusluule ja Koidula luule vahel: "Suits on sel edenemisastmel veel rahvusline, isamaaline vanas, hääs romantilises tähenduses. [---] Tundub selgesti temperamendihõimlus Koidula ja Gustav Suitsi noorusluuletusis, hoolimata nende järgneva arenemise täielikust erivusest" (Kallas 1921: 58-59).

Nooreestlastest ühe esimesena hakkas Suits oma kirjatöödes tegelema rahvaluulega, rääkides alles äsja ülikooliteed alustanult natuke meie rahvaluule 


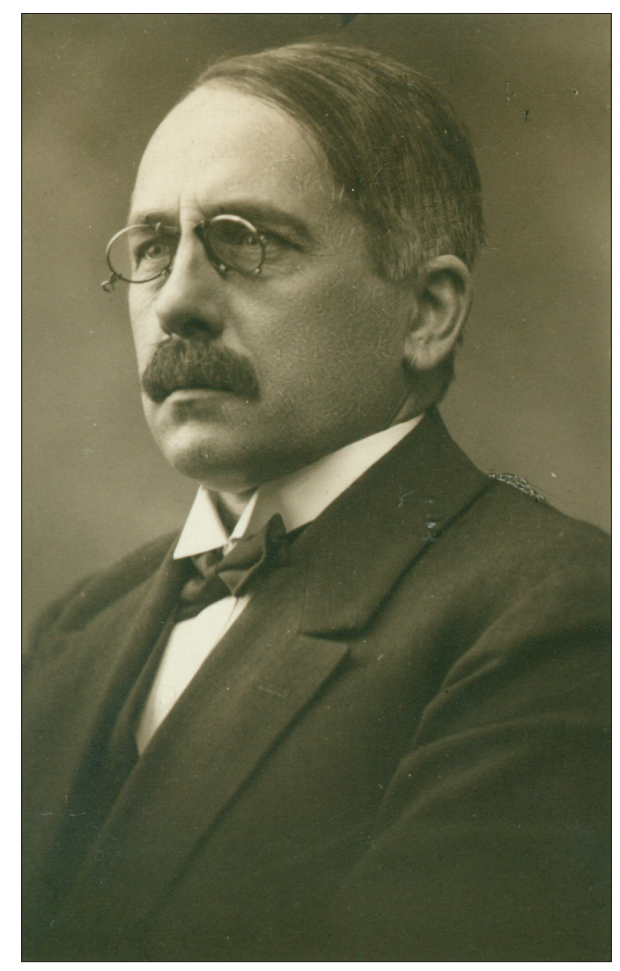

Foto 3. Gustav Suits. Foto: EKLA, A198: 106.

kogumise-uurimise esimestest märkidest artklitekogumikus Sihid ja vaated (Helsingi 1906). Jakob Hurda surma puhul kirjutas ta nekroloogi, mis sisaldab hinnangulise ülevaate Hurda tegevusest (Suits 1907). Kirjutises on öeldud, et Hurt kui omaaaegne "nooreestlane" tõi suure pööripäeva nii meie ühiskondlikku ellu kui ka rahvaluuleteadusesse. Suits imetleb Hurta, kes hoolimata seisuslikust sõltuvusest pastorina suutis nii tulemuslikult Eesti elust osa võtta; ja kui ta eemale tõrjuti, ei löönud ta käega, vaid avalikust tegelasest Jakob Hurdast sai teadusemees dr. J. Hurt. Suits on kindel, et suure töötegija ja isamaalase nimi jääb alatiseks elama rahva tänulikus mälus (Suits 1907 (5): 1).

Suitsu rahvaluulega seotud tegevusest võib saada teavet Eduard Laugaste artiklist "Gustav Suitsu sidemetest rahvaluulega" (Laugaste 1992: 109-126), kust selgub, et Suits on juba üliõpilasena tutvustanud meie rahvaluulet ka väljaspool Eestit, kirjutades Eemil Nestor Setälä soovitusel eesti kirjanduse ülevaate koguteosele Die Kultur der Gegenwart (1908), toetudes oma käsitluses peamiselt soome teadlaste uuringutele. 
Ülikoolis kuulas Suits Kaarle Krohni loenguid mütoloogiast, soome rahvalaulude ajaloost, Kullervost jms, üht-teist võib selle kohta lugeda Ilmar Talve artiklist Tulimullas, kus tulevad esile ka mõned külastused Kallaste peres (Talve 1953: 337-359). Suitsu töödest kumab läbi ka huvitumine Julius ja Kaarle Krohni poolt väljatöötatud geograafilis-ajaloolisest uurimismeetodist: tema koostatud antoloogia Eesti lugemisraamat (I osa 1916, II 1919) esimeses osas on ära toodud paar regilaulu (üks neist J. Hurda ajalooalase kirjutise "Pildid isamaa sündinud asjust" tekstikatkes), teises osas aga Oskar Kalda rahvalaulude migratsiooni käsitlev artikkel "Eesti laul rännuteel” koos lühitutvustusega autorist (Suits 1919: 232-236). Suitsu jätkuvast regilaulu-probleemistikku süvenemisest annab märku tema ja Aaviku vahel tekkinud vaidlus regilaulu skandeerimise küsimuses. Aastatel 1924 ja 1925 ilmus tal Loomingus Suitsmaa nime all kaks selleteemalist artiklit (Suitsmaa 1924: 538-542; Suitsmaa 1925: 268-270). Aavik soovitas koolis õpetada regivärsse lugema skandeerides, ja see on ilmselt esile kutsunud Suitsu kirjutiste terava ja iroonilise tooni. Suits teeb vahet leelotamisel ja lugemisel. Rõhutamist väärib aga, et Suits peab vana rahvalaulu õpetamist koolis väga vajalikuks.

Kalevipoja terav kriitika sai õieti alguse Kaarel Leetbergi ettekandest "Kui pikalt on "Kalevipoeg" rahva luuletus?", mille ta pidas Peterburis aastal 1911, kui eepose ilmumisest oli möödunud 50 aastat. Tartus samal puhul Eesti Kirjanduse Seltsi poolt korraldatud ettekandekoosolekul esines Suits, ettekanne on ilmunud artiklina Eesti Kirjanduses (Suits 1911: 449-461). Ta leiab, et eesti rahva vaimuelule andis eepose ilmumine hoopis uue sihi: ilma Kalevipoja nõiavõimuta ei oleks rahvuslik liikumine saanud sellist jõudu, mis pani nimeta maarahva orjapõlve unest ärkama ja eneseteadlikuks eesti rahvaks saama; muus maailmaski huvituti nüüd esmakordselt rahvast, kellel on midagi $\mathrm{Ni}$ belungenliedi väärilist. Kuigi Kreutzwald on rahvalikud ained enda ja ajajärgu maitse järgi ümber töötanud, on see ikkagi rahvuslik töö, mis peegeldab rahva mõttemaailma ja avaldab mõju rahvusliku arenemise peale. Edasi leiab Suits, et kriitikata suhtumine pole 50 aastat pärast eepose ilmumist enam võimalik, nüüdne folkloori- ja esteetika-alaste teadmistega teritatud pilk ei vaatle Kalevipoega ainuüksi imetlevalt ega ka ainuüksi mahakiskuvalt, vaid küsivalt ja selgust otsivalt; viimast sõna ei saa aga öelda ilma põhjaliku uuringuta. Hiljem, juba õppejõuna, suunaski ta sellele tööle oma õpilase August Annisti, kelle erudeeritud uurimus kinnitas rahvuseeposele meie kultuuriloos väärilise koha. ${ }^{2}$

Niisiis oli Suits Kalevipoja küsimuses veidi teist meelt kui Aavik, Tuglas ja Ridala. Kuigi ka nende suhtumises oli erinevusi (eepose rahvuslikku tähtsust tunnustasid nad siiski kõik), olid nad üsna üksmeelsed eheda regilauluga võrdlemisel ilmnevate keeleliste, värsitehniliste ja stiililiste puuduste suhtes. Pagulaspõlves Lundis 1953. aastal avaldatud kirjandusloos räägib Suits pea- 


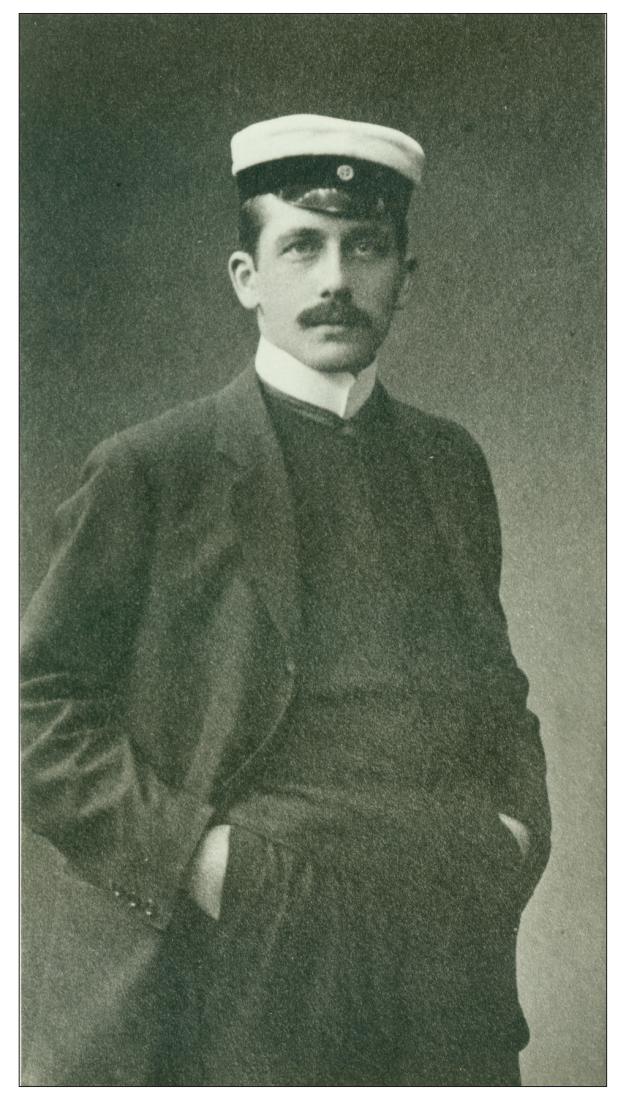

Foto 4. Gustav Suits üliõpilasena. Foto. EKLA, B 198: 57.

miselt eepose valmimisloost ning rahvuslikust väärtusest (Suits 1999: 188). Rahvaluulet Suits kirjandusloos otseselt ei käsitle, kuid vajadusel viitab sellele.

Suitsu regilauluhuvi väljendub selgeimalt tema enda regivärsilises luules. Kõigepealt tuleb nimetada esikkogus Elu tuli (Helsingi, 1905) ilmunud pühendusluuletust "Üks ennemuistne jutt. Lauluisa Kreutzwaldi varjule". Regivärsielemente on selle kogu mõnes muuski luuletuses, näiteks "Rõõm ja mure". Kogumikus Ohvrisuits. Valik armastusluuletusi. 1904-1920 (Tallinn 1920) on ilmunud seitse lüürilist luuletust pealkirjaga "Primitiivid. Uusi keeli vanal kandlel". Ka on kogumikus Kõik on kokku unenägu (Tartu 1922) regilaulul põhinevaid luuletusi: "Primitiivid" (mõnevõrra muudetuna), "Viimne päev", "Mõistke, mõistke!" Sama võib öelda paguluses ilmunud kogumikust Tuli ja tuul (Stockholm 1950), kus ilmunud pikemat luuletust "Kolmeteistkümnes juuli. Ballaadi asemel” võib lausa regivärsiliseks nimetada. Märgatavalt regivärsiele- 
mente on veel luuletustes "Võnnu motiive" ja "Kodust ilma". Suitsu regivärsiluulest on muidugi kõige olulisem poeem "Lapse sünd", alapealkirjaks samuti "Uusi keeli vanal kandlel". Poeem on kirjutatud juba 1914. aastal, esimese tütre sünni puhul, kuid ilmus raamatuna aastal 1922 (Tallinn: Varrak, 1922.) Selles luuleteoses nähtub Suitsu väga hea regivärsilise rahvalaulu tundmine (vt ka Mirov 2007: 1861-1875).

\section{Villem Grünthal-Ridala}

Villem Grünthal-Ridala lõpetas Helsingi ülikooli aastal 1909 (magistrikraad 1911, doktorikraad 1941). Tema folkloristikaalaseks laudatur-tööks oli Setu rahvalaulude sõnastik.

Aaviku puhul oli juba juttu, et aastatel 1918-1919 ilmus ühtekokku viis regilauluvalimikku. Valimike koostajate hulgas oli teinegi nooreestlane - Villem Ridala (Ridala 1919). Nagu Aavik, nii ütleb ka Ridala, et koostamisel on silmas peetud ennekõike esteetilist vaatekohta ning püütud leida laulude hulgast ilusamaid ja sisukamaid. Vaade esteetilisele on autoritel natuke erinev: Ridala pani rõhku hoopis murdekeelele ja püüdis seda säilitada nii esteetilisest kui ka pedagoogilisest seisukohast lähtudes. Saatematerjaliski tõuseb esile keeleaspekt: valimiku eessõna sisaldab ülevaate regilaulukeelest, lõpus on sõnastik. Eespool on juba mainitud, et hiljem, kui hakati ennekõike just Kaarle Krohni initsiatiivil koostama lüroeepiliste regilaulude suurväljaannet Eesti rahvalaulud Dr. Jakob Hurda ja teiste kogudest, kuulus teose esinduslikku, Eesti ja Soome rahvaluuleteadlastest koosnevasse toimetajatekogusse ka Villem Grünthal.

1912. aastal on Ridala avaldanud pikema artikli "Eesti rahvaluule" (Grünthal 1912: 395-403, 484-511), mis mingis mõttes kuulub kokku tema esseega “Tõu küsimus” (Tartu, 1914), kuna rahvaluulet käsitletakse selles laiemal soomeugrilisel areaalil, tuues palju võrdlusmaterjali teistelt soome-ugri rahvastelt, rääkides sinna juurde ka tõulistest ja klimaatilistest tingimustest. Kõnealuses artiklis on jutt peamiselt vanast (eestlastel siis regivärsilisest) rahvalaulust. Ridala seisukohalt on loomingu aluseks religioon (ta ütleb, et rahvaluule on maagilist, sakraalset, usulist algupära) ja seega on muutused meie rahvalaulus seostatavad muutustega religioossetes tõekspidamistes (Grünthal 1912: 402). Elulaadi muutuste suhtes on sisust püsivam olnud regilaulu vorm, mida Ridala tajub aegadest läbi ulatunud jõudude kontsentratsioonina. Regivärsivorm on arenenud ja kindel, omas kujus täiuse saavutanud (Grünthal 1912: 506-507).

Ka Ridala on koostanud koolidele mõeldud kirjandusloo, selle esimene osa ilmus 1922. aastal (Ridala 1922). Selles räägitakse ülevaatlikult rahvaluulest 


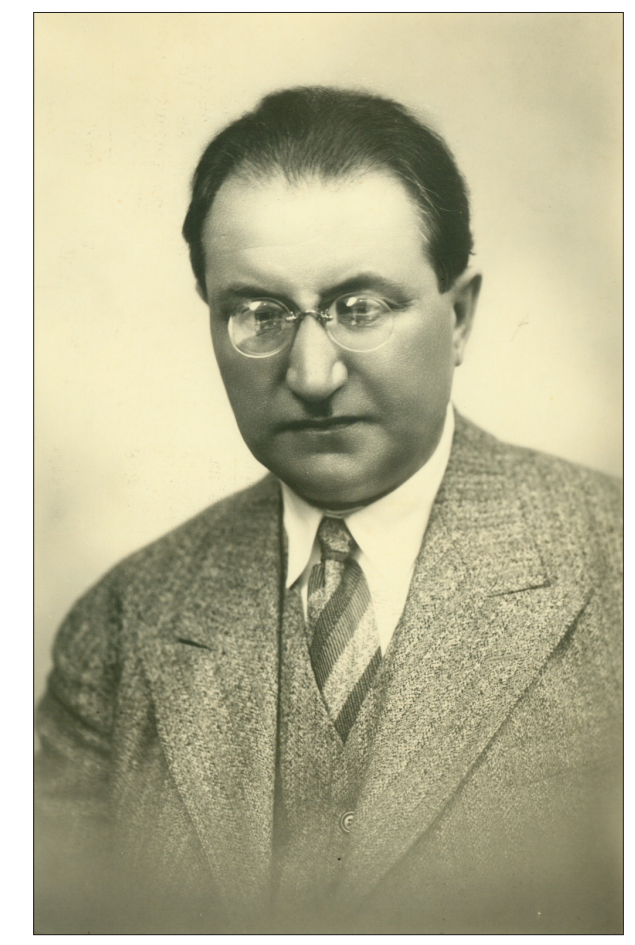

Foto 5. Villem Grünthal-Ridala. Foto: EKLA, A3: 392.

lehekülgedel 5-12 ning Kalevipojast lehekülgedel 38-44. On märgitud, et Kalevipoeg kannatab kõige enam stiililiste puuduste all, kuid kõigist ebakohtadest hoolimata on temast saanud oma ajastut tähistav suurteos. Ka toob Ridala esile terve rea õnnestunud episoode, nimetades neid parimaks, mis eesti kirjandus seni üldse on loonud. Ridala sõnul sisaldab Kalevipoeg ühe kõige traagilisema inimelu kujutuse, mis üksikisiku kaudu annab pildi kogu rahva traagilisest saatusest, ja see on meie oma rahvas (Ridala 1922: 44). Teine, parandatud ja täiendatud trükk ilmus 1924. aastal (Ridala 1924). Selles on vaadeldud kõiki rahvaluuleliike. Kõige põhjalikum on rahvalaulude käsitlus, mis koos näidetega hõlmab viiskümmend lehekülge. Räägitakse ka kogumisest, uurimisest ja väljaannetest ning autor leiab, et meie rahvaluule on niisugune väärisvara, millist harva suurtelgi rahvastel leidub. Veel on olemas teos Kalevipoeg. Kirjutanud V. Ridala (Ridala 1921), mis on eepose proosaümberjutustus. Allkirjaga W. Grünthal-Ridala "Esikõnest" loeme, et puudustest hoolimata on Kalevipoeg meie kirjanduse suurteos ja nagu varaait sisaldab ta kõige erilaadsemaid rahvaluule-aineid "suures paljuses ja kirjavas mitmekesisuses" (Ridala 1921: 5). 
Raamat on välja antud ka Soome keskkoolide ja seminaride tarbeks (Ridala 1929). See sisaldab Helmer Winteri eessõna, kus Kalevipoega nimetatakse hõimurahva seni võitmatuks kirjandusteoseks, parimaks aardeks. Eepose ümberjutustus ise on eestikeelne, mõeldud siis ka abivahendiks kaasaegse eesti keele õpetamisel.

Keeleteadlasena huvitas Ridalat regilaulude arhailine keel ning ta on avaldanud sellekohase artikli "Eesti rahvaluule keelest" (Ridala 1931: 266-286). Ka on ta käsitlenud keelt poeetilisest aspektist (Grünthal 1933: 102-119). Samuti on Ridala avaldanud rahvalaulul põhinevate teoste tõlkeid: Eino Leino kalevalavärsilised ballaadid on ilmunud 1923. aastal pealkirjaga Pühad laulud; Kalevala tõlge on jäänud käsikirja, ilmunud on sellest vaid Kullervo-tsükkel ja esimene runo. On arusaadav, et sellised tõlketööd nõuavad nii soome kui ka eesti rahvaluule head tundmist.

Loomulikult seostus rahvaluulega Ridala pedagoogitegevus gümnaasiumiõpetajana ja õpetajate suvekursuste lektorina, teadaolevalt on ta õpetamisel harrastanud ka Kalevala ja Kalevipoja võrdlemist, eriti värsitehnilisest aspektist, toetudes sealjuures pärimuslikule rahvalaulule. Helsingi ülikooli eesti keele ja kirjanduse lektorina luges ta ka rahvaluule üldkursust, samuti kuulus õppeprogrammi üksikute regilaululiikide põhjalikum käsitlus ja laulutekstide analüüs (andmeid selle kohta leidub Helsingi ülikooli arhiivis). Tema loengutest ülikoolis räägib ka Riho Grünthal artiklis, mis on ilmunud raamatus Kultuurisild üle Soome lahe (Grünthal 2005: 257-260).

Ja eriti oluline - Ridala on see eesti luuletaja, kes on kõige rohkem kirjutanud regivärsilist luulet. Just tema eepiline ja lüroeepiline luule on suures enamuses regivärsiline: poeemid Merineitsit (Tartu 1918), Toomas ja Mai (Tallinn 1924) ja Püha Rist (Tallinn 2005) ning ballaadikogu Sinine kari (Tartu1930). Nagu Ridala ise on maininud, on ta mõlema suurpoeemi, Toomas ja Mai ning Püha Rist, kirjutamiseks inspiratsiooni ja ideid saanud, pidades ettekandeid regivärsilisest rahvalaulust. Saanud aastatel 1930-1931 valmis Uue Testamendi neljal evangeeliumil põhineva Püha Risti käsikirja, asus ta üsna varsti ümbervärsistama Kalevipoega. Seegi suurtöö on olemas käsikirjas. Väike näide on ilmunud: "Soovituseks" (Looming nr 4, 2006, lk 579-580). Kalevala tõlkimine, Kalevipoja ümbervärsistamine, Püha Risti loomine - juba ainuüksi kõnealuste tööde mahukus annab ainet järelemõtlemiseks. Kuid tasub mõelda ka sellele, et tegu on maailmakultuuri suurteostega. Kuigi alustekstid iseenesest ju samasse tunnetuskategooriasse ei kuulu, on Ridala regivärsistuses ka Uue Testamendi evangeeliumid saanud kirjandusteoseks (nüüdseks on teos ka trükis ilmunud - Ridala 2005). Ja nagu öeldud, hindas Ridala eriti kõrgelt just ürgset regivärsivormi. Püha Risti puhul võiks siis oletada omapärast ideaalitaotlust, püüet saavutada mingit ülitaset väärtusliku sisu ja väärtusliku vormi ühenda- 
misega (vt ka Mirov 2005: 434-438). Kalevipoja ümbervärsistamise puhul oli muidugi tegu katsega anda rahvuseeposele "õigem" keelekuju ja värsivorm (vt ka Mirov 2006: 569-578). Muid aspekte kõrvale jättes kinnitab Ridala selline süvenemine regilaulu-maailma, maailmakultuuri suurteoste regivärsistamine, ühe Noor-Eesti kirjamehe eriti sügavat kiindumust muistsesse luulesse ja luuletehnikasse.

Juba poeemi Merineitsit puhul on Aino Kallas kirjutanud järgmist: "Ridala ei hakka sest ainest kinni mitte nüüdisaegsena kirjanikuna. [---] Ta pole üksi katsund arkailisse aega süüvida, vaid ka uuesti arkailisena laulikuna sündida, ühena rahvaluule lugematuist runolauljaist, kelle kollektiivse loomingu vili on muistne rahvaluule" (Kallas 1921: 95). Rääkides raamatust Sinine kari ütleb Elsa Niinivaara, et neis ballaadides on Ridala saanud öelduks oma igavikulised sõnad (Niinivaara 1981: 229).

Siiski ei saavutanud Ridala regivärsiline luule suurt tähelepanu. Olgu siinkohal esile toodud ka mõned Suitsu sellekohased märkused tema kirjandusloos. Suitsu sõnul on Ridala regivärsilisest luulest vististi kõige ebapopulaarsemaks jäänud Toomas ja Mai, aga ta lisab: kui see teos eelarvamusteta kätte võtta, võib sealt leida "mitte ainult folkloristlikke ja filoloogilisi väärtusi”. Ning rääkides Sinisest karjast ütleb Suits, et soome keeles ilmunud antoloogias Eestin runotar paistab ballaad hoopis uues veetlevas valguses (Suits 1999: 395). Suitsu väide on täiesti mõistetav, kuna soome keeles ei ole toimunud sellist sõnade totaalset lühenemist nagu eesti keeles (just mõlemat kirjakeelt silmas pidades), siis ei teki võõrastust, mis arhailiste sõnakujude puhul võib tekkida eesti keeles, eriti kui selline sõnakuju on kunstlikult loodud.

Riho Grünthal on aga esitanud järgmise seisukoha: "On alust arvata, et Villem Grünthal-Ridala kirg regivärsilise vormi ja eepilise ainese vastu leidsid rohkem kõlapinda tolle aja Soome kultuurielus kui Eestis, eriti hõimurahvameelsetes akadeemilistes ringkondades, kus hõimuliikumine oli populaarne ja arenes välja Kalevalast ja karenialismist mõjutatud rahvuslikus mõtteviisis" (Grünthal, R. 2005: 271).

\section{Friedebert Tuglas}

Siinses artiklis peaks Kalevipoeg õieti kõrvaliseks jääma, põhirõhk on ikka pärimuslikul, ehedal regilaulul ja selle hindamisel Noor-Eesti nelja keskse kirjamehe poolt. Kuid Kalevipoeg on olnud stiimuliks kõnealuste kirjameeste regilaulusse süvenemisel, nii tuleb eeposest siiski üht-teist rääkida, kõige enam seoses Tuglasega. 


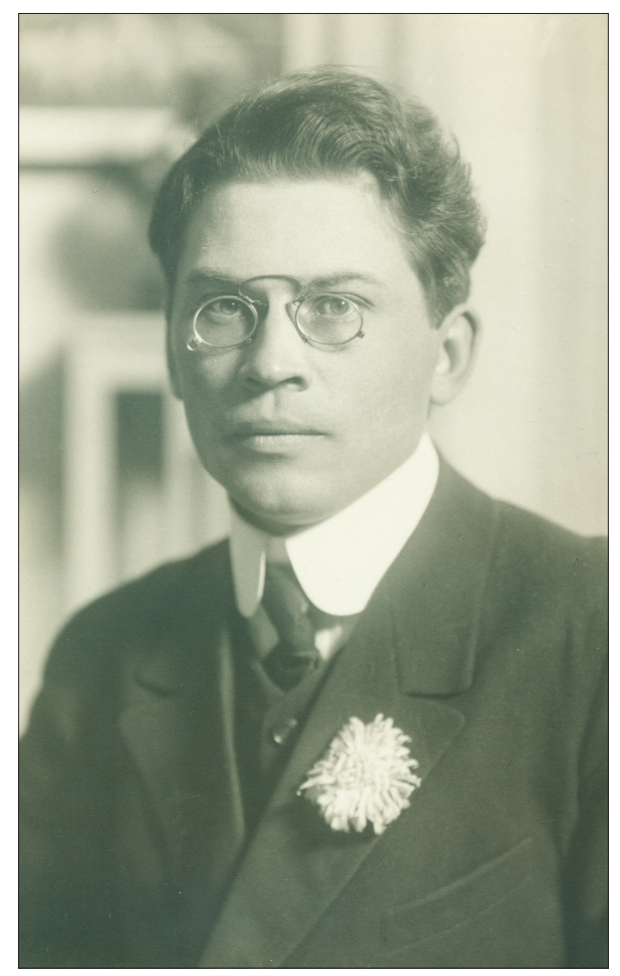

Foto 6. Friedebert Tuglas. Foto: EKLA, A37: 1639.

Kahtlemata ei ole Tuglaski oma loomingus rahvaluule-elemente rakendamata läbi saanud, alates peaaegu poisipõlves kirjutatud pajatuse-laadsest külajutust "Hunt". Hilisemate sümbolistlike teoste puhul on mõnedele rahvaluule-elementidele osutanud Ants Järv (Järv 1992: 99-108). Ideede ja ainete andjaks on Tuglasele olnud ka pahaks peetud Kalevipoeg - näiteks novell "Maailma lõpus", mis tekitas koguni vaidluse Aira Kaaluga (Tuglas 2004: 177-182). Regilaul värsivormina ja sõnastusmaterjali otsese allikana Tuglase kui proosakirjaniku loomingus osaline pole, ometi võib paaris tema noorusaegses luulekatsetuses märgata regilauluelemente, näiteks eestlaste aja- ja kultuurilugu kajastav kuue-osaline luuletus "Tuhat aastat" (ilmunud väljaande Vabaharidustöö erinumbris Kirjandusnädala album).

Siirdunud 1906. aastal pagulasena Soome, tekkisid Tuglasel Soome-Eesti Liidu kaudu kontaktid professor Kaarle Krohniga ning arusaadavalt suhtles ta Helsingi ülikoolis õppivate Aaviku, Suitsu ja Ridalaga. Selles õhkkonnas on iseenesestmõistetav Tuglase jätkuv huvi rahvaluule vastu. Kuid Tuglasel 
on tegelemine rahvaluulega algusest peale väga tugevalt seotud Kalevipojaga. Õigem ehk teistpidi - huvi Kalevipoja vastu tõi kaasa tegelemise rahvaluulega. Tema esimesi kirjandusteoreetilis-folkloristlikke uurimusi on "Põrgu väravas", milles ta otsib Kalevipoja lõppepisoodile paralleele mitme rahva müütidest, jälgides peamiselt kangelase aheldamisest jutustavaid pärimusi. Ulatusliku allikmaterjal hulgas on ta saanud kasutada ka Jakob Hurda Setukeste laule ja Elias Lönnroti Kanteletari. Uurimus ilmus kõigepealt 1908. aasta Eesti Kirjanduse kuues numbris (Mihkelson 1908: 224-232, 258-270, 301-307, 325-331, 352-361, 387-392). See teema ja Tuglase see uurimus on pälvinud nimekate teadlaste tähelepanu. Felix Oinas on sama teemat käsitlenud terves reas artiklites, paari neist võib leida ka tema artiklikogumikust Surematu Kalevipoeg (Tallinn, Keel ja Kirjandus 1994). Jaan Undusk on Tuglase artiklist kirjutanud uurimuse, mis on ilmunud Keele ja Kirjanduse 1990. aasta kolmes viimases numbris (Undusk 1990: 587-597, 645-656, 720-735). August Annist puudutab Tuglase artiklit oma Kalevipoja-uurimuse esimeses ja kolmandas osas.

Selgelt kriitiliste seisukohtadega Kalevipoja suhtes esines Tuglas essees "Kirjanduslik stiil", mis ilmus Noor-Eesti neljandas albumis 1912. aastal. Aegade jooksul polnud Tuglas ju ainus eepose range kriitik, kuid küllap üks mõjukamaid.

Essee "Kirjanduslik stiil" algab rahvaluulekäsitlusega, ja see algus on kohati üsna ilutsev, eriti selle korduvalt ilmunud kirjutise esimestes redaktsioonides. Siit-sealt võiks lausa rahvaluule ülistust välja lugeda: rahvalaulust ja laulikneidudest on loodud kaunis kujutluspilt "Ilulaulu" abil; regilaulust räägitakse kui üdini naiselikust, lüürilisest luulest, ja leitakse, et nagu laulik ise, nii läheb ka tema fantaasia liikvele varastel, hämar-udustel hommikutundidel. "Meie rahvalaulu parallelism, mis annab sellele luulele erilise hämara ilu ja impressionistliku meeldivuse, on võimatu täpsas, realistlikus uueaja keeles" (Tuglas 1996b: 420). Tuglas nendib ka, et rahvaluules valitseb sama esteetiline printsiip nagu kunstis üldse - rahvas on osanud esteetiliselt näha (Tuglas 1996b: 415-416). Kuid arutledes pikemalt regilaulu parallelistliku ülesehituse, alliteratsiooni jms üle leiab ta üldistavalt, et kunstilised piirid on siiski kitsad. "Rahvalaulu alliteratsioon muutus türanniaks, mis takistas uudusi ja sundis käima šablooni järgi" (Tuglas 1996b: 419). Konservatiivne vorm on omalt poolt ka ainete valikut mõjutanud. "Rahvalaulu ainete vald muutus tüüpiliseks, kõvaks kivinenuks, mille piiri ei või ilma stiili ja maitse instinkti haavamata ületada" (Tuglas 1996b: 420). Edasi leiab Tuglas: "Eesti rahvalaulude värsimõõdus ja rütmis on midagi väsitavat, ühetoonilist ja tuima. Sellepärast on meil raske järgemööda suuremat hulka neid laulusid lugeda. [---] Otse igatsusega ootame maitserikkalt ja hoolikalt koostatud valikut, et siis ainult veel uurimise otstarbel Monumenta Estoniae Antiquae hiigelköiteid avada" (Tuglas 1996b: 
420). Ja järeldusena: "Meie rahvalaul - see on ainult üks võimalus. Kuid stiilil peab olema palju võimalusi. Kunstkirjandus ei tungi ainult individuaalse sisu, vaid niisama ka individuaalse vormi poole. Ja sellepärast ei rahulda teda ka meie rahvalaulu küll huvitav, kuid siiski kitsas väljendusvõimalus" (Tuglas 1996b: 420). Üksikute tsitaatidega ei saa muidugi edasi anda Tuglase arutluse kogu sisu. Pealegi on erinevusi, peamiselt küll sõnastuslikke, artikli eri redaktsioonide vahel. 1959. aasta asjalikuma sõnastusega redaktsioonis tuleb selgemalt esile kokkuvõtlik seisukoht, et regilaulu vorm ja stiil oli vastavuses omaeaegse elu ja oluga ning aegade muutudes pidi luule vorm ja stiil, nagu ka temaatika, muutuma. Tuglas ei halvusta regilaulu, ta nendib vaid tõsiasja: selline luuletava, omas laadis küll täiuslik, ei vastanud enam muutunud elulaadile. Loomingulise individuaalsuse, värsivormide mitmekesisuse ülistamisel läheb Tuglas aga nii kaugele, et annab võrdlemisi hea hinnangu meie uuemale rahvalaulule, mida üldiselt on regilaulust kunstiliselt madalamaks peetud. Kuid Tuglas ongi ju selle artikli kirjutanud ajal, kui individuaalsus oli tema loomingulise tegevuse juhtmõtteks.

Arutluses regilaulu üle toob Tuglas esile ka järgmise mõtte: "Meie rahvalaulud on oma kitsal alal täiuseni tõusnud. Nad pakuvad teatud määra vormimaterjali ja omapärast käsitlemismeetodit ühes luuleliste ainete ning meeleoludega. On sellepärast loomulik, et mõte tõuseb neid rahvalaulu elemente kunstluules uuesti kasustada. Ühelt poolt avatleb rahvalaulude liitmise, teiselt poolt nende imiteerimise võimalus. Sellesihilised katsed on aga siiamaale vähe õnnestunud. [---] Selle väite parimaks illustratsiooniks kõlbab meie kunstlik rahvaeepose loomise katse ..." (Tuglas 1996b: 422-423). Kalevipoja puudustest rääkides osutab Tuglas siiski selle kohatist luuleväärtust, üksikute lüüriliste laulude ja kõrvalstseenide ilu, mille on mõnikord taganud Kreutzwaldi enda looming, enamasti aga eepose tekstis rakendatud rahvalaulud.

Essee "Kirjanduslik stiil" 1935. aasta redaktsioonis on Tuglas üldse eitav regivärsilise kunstluule suhtes. Ta leiab, et kardetav on nii imiteerimine kui ka suuremate kompositsioonide kokkuliitmine: "Hurt on oma "Kahes keeles" maksimumi näidanud, mis rahvalauluga võib korda saata" (Tuglas 1996b: 430-431). Sellega on piirid küll väga kitsaks tehtud, sest Hurt oma "kaht kandlekeelt" - "Ilulaulu" ja "Kalmuneidu" - kokku seades on kasutanud ainult sama laulutüübi eri variantidest pärinevaid värsse.

Veel põhjalikumalt kui essees "Kirjanduslik stiil" arutles Tuglas meie rahvuseepose puuduste üle artiklis “"Kalevipoeg”. Mõtteid teose parandamise puhul” (algselt ilmunud pealkirjaga “"Üks ennemuistne Eesti jutt”. Mõtteid "Kalevipoja" parandamise puhul" - Päevaleht 1916, 16.-18. nov, nr 258-260). Tuglas võrdleb Lönnroti ja Kreutzwaldi loojaisiksusi: Lönnrot - rahvalaulik ja kokkuliitja, Kreutzwald - luuletaja ja artist, viimasega mõeldes vist indi- 
viduaalset loojaisiksust, mis vastandub rahvaluule käsitamisele kollektiivse loominguna. Tuglas hindab Lönnroti oskust sellesse loojatekollektiivi sulanduda. Kokkuvõtvalt leiab ta, et eesti rahvaluules ei leidunud aineid sedalaadi rahvaeepose jaoks, nagu seda tahab olla Kalevipoeg, ning Kreutzwaldil puudusid rahvaeepose looja omadused (Tuglas 1996c: 81-82). Ja Tuglas tõdeb: "Jäi vaid meeleheitlik simulatsioon rahvaluule varju all” (Tuglas 1996c: 84).

Silmas pidades peamiselt regilaulu, rõhutab Tuglas juba varem öeldut: "Rahvaluule sisu ja vorm pole arenematu, vaid esitab omal alal just täiust. Rahvaluulega ei või midagi vabandada, see ainult kohustab. Rahvaluule ei "tee stiili", sest ta on stiil iseenesest. Ja just siin näeme Kreutzwaldi nõrgemaid külgi. Ta ei tundnud rahvaluule piire, ta on neid ühtesoodu ületanud. Ta teeb "stiili", ta liialdab, ta ei tunne üldse seda maailma, mille nimi on rahvaluule" (Tuglas 1996c: 85). Ning edasi: "Nii raske kui see ehk näib praegu, kui Kreutzwald hoopis ise vaimus vormi on loonud, peame ta teose rahvalaulu keelde tõlkima. Sest see oleks ainus võimalus, ainus reaalne stiil, millele toetuda. Sellepärast tuleb teos vormilt algusest lõpuni ümber luua, ümber jutustada, parafraseerida isegi rahvalaulu kohad "Kalevipojas", sest on tõendatult selge, et Kreutzwald neidki on oma ebarahvaluulemaitse seisukohalt rikkunud" (Tuglas 1996c: 95). Siinkohal võib siis öelda, et Tuglas asub regivärsiliste rahvalaulude suhtes lausa kaitsepositsioonile, kuna tema arvates on Kreutzwald nende keelt, värsiehitust ja stiili kahjustanud.

Tuglase 1934. aastal ilmunud kirjandusloos (Tuglas 1934) on kümmekond lehekülge rahvaluulest. Siin kinnitab Tuglas, et rahvaluule väärtuslikum ja kindla vormi tõttu objektiivsemalt hinnatavam osa on rahvalaul. Viidates nüüd Oskar Looritsale, ütleb Tuglas, et vabaduse kaotamisele järgnesid nn passiivse vastupanu sajandid ning luuleloomingus hakkas sündmustest jutustava eepika asemel arenema naiselik meeleolude lüürika. Eesti rahvalaulik ongi olnud eriti viljakas puhtlüürilisel alal ning rahvalaulude temaatika on rikas - laulud saadavad inimest hällist hauani. 1939. aastal ilmus Tuglase kirjanduslugu soome keeles (Tuglas 1939), milles on rahvaluulest samuti lühidalt juttu. Esile tuuakse samu seisukohti, mis leidsid väljendamist juba eestikeelses kirjandusloos: viikingiaja mehelik elutunne ja aktiivne meelelaad ning sellega seonduv eepiline luule kadus pärast muistse iseseisvussõja lõppu. Neis väidetes tugineb ta siingi folkloristikas pädevamatele isikutele - Ridalale ja Looritsale. Juttu on ka Jakob Hurdast ja rahvaluulekogumisest. Veel on märgitud, et suurim kirjanduslik saavutus rahvaluule baasil on Kalevipoeg, ning nüüd on rahvaluulet oma loomingus kasutanud ka Suits, Ridala ja Eisen, aga viljakam aeg on ehk veel ees (Tuglas 1939: 14). Hõimurahvale suunatud kirjandusloos on toonid nii Kalevipoja kui ka muu kirjandusliku regivärsilise luule suhtes leebemad kui varasemates kirjutistes. 


\section{Lõpetuseks}

Niisiis, juba ainuüksi Tuglase tõttu tuli käesolevas artiklis võrdlemisi palju rääkida Kalevipojast, kuna tema suhtlemine regilauluga ja üldse rahvaluulega on käinud peamiselt Kalevipoja kaudu. Teised kolm kõnealust nooreestlast olid küll Helsingi ülikoolis kõrgtasemel rahvaluulet õppinud, aga Kalevipoja ümber toimunud väitlus aktiveeris ka nende tegelemise regilauluga. Muidugi on Aaviku ja Tuglase omaaegsed ülikriitilised seisukohad Kalevipoja suhtes ülepakutud ja ülekohtused, seda on August Annist oma uurimusega ammu tõestanud. Aaviku ühekülgse kriitika kohta ütleb Annist nii: "Aga doktrinäärse esteedina ei osanud ta mõista "Kalevipojagi" värsimõõdu ja stiili omapära, millel on o m a d väärtused, vaid tahtis teda n-ö vägisi tõmmata "Kalevala" liistule" (Annist 2005: 41). Annistil on muidugi õigus, aga ka Aavikut ja Tuglast, samuti Ridalat võib mõista. Teoreetilises plaanis oli tol ajajärgul küll suunda andev estetism, mida Tuglas ka eepose ümbervärsistamise üldprintsiibina esile toob. Kuid soov parandada Kalevipoega lähtus ilmselt ikka tähtsamast ja üldisemast eesmärgist - tõsta meie kirjanduse taset. Eesmärgi võib ka niimoodi sõnastada: eestistada "germaaniline "Kalevipoeg"' (Tuglase väljend), pannes ta õigesse eesti regivärssi ja õigesse eesti keelde. Seda Aavik ja Ridala püüdsidki teha. Kindlasti oli sealjuures oma kaasmõju kujunemisaastatel Soome kultuuriväljas - eepilistel rahvalauludel põhinev Kalevala ja häälikute kvantiteeti arvestav kalevalavärss olid saanud ideaaliks.

Käesoleva kirjutise kontekstis võib aga veel kord rõhutada järgmist: kuna eepose lahkamine toimus võrdluses pärimusliku regilauluga, mida eriti Aavik üksikasjalikult analüüsis, sündis kritiseerimise kõrvalproduktina regilaulu keele ja poeetilise võttestiku asjakohaseid kirjeldusi. Regilaul leidis hindamist kui stiilne kunstinähtus, millel on väljakujunenud, omapärane vorm ja väljendusrikas kujundikeel. Regilaulu nähti väärisluulena.

Kalevipoja küsimus püsis päevakorral aastaid ning ilmselt oli selle üks tagajärgi, et kirjanike hulgas tekkis rohkem huvi regilaulu ja üldse rahvaluule kirjandusliku rakendamise vastu. Kuna huvi lähtus eepostest, on mõistetav, et sündis peamiselt (lüro)eepilisi teoseid (vt ka Mirov 2002: 447-470). Tuglase kirjutistes esinev mõte, et muistsel vabadusajal eksisteerinud mehelik eepika sumbus orjaaja kitsastes elupiirides ja asendus naiseliku lüürikaga, tõstis eepilise rahvalaulu lüürilisest kõrgemaks ja tähtsamaks. Arvata võib, et siin on peidus lisapõhjus, miks tekkinud regiluulehuvi tootis peamiselt eepilist ja lüroeepilist luulet. Regiluulet hakkas tekkima juba Kalevipoja parandamismõtete laineharjal: 1914. aasta algul kirjutas Suits poeemi Lapse sünd, mis ilmus küll alles 1922. aastal. ${ }^{3}$ 
Ridala esimene regivärsiline poeem Merineitsit ilmus ligilähedalt samal ajal, 1918. aastal, oli aga valminud juba paar aastat varem. Ja hilisemadki teosed jätkavad ju ikka sedasama, eepostest sünnitatud regiluule jada. Villem Ridala, Gustav Suitsu ja Johannes Aaviku ning nende kaasaegsete ja järgijate regivärsiline (lüro)eepika on kahtlemata omaette nähtus meie kirjandusloos.

Eespooltoodud lünklikust ülevaatestki on selge, et kõik kolm Helsingi ülikoolis folkloristikat õppinud nooreestlast on elu jooksul teinud päris palju tööd ka otseselt rahvaluule, peamiselt küll regilaulu, uurimisel ja tutvustamisel. Tundub tõepoolest, et nad on midagi pärinud professor Kaarle Krohni jäägitust erialale pühendumisest. Kõigepealt juba Ridala ja Aaviku regilauluvalimikud oma mitmesuguste lisadega. Samuti Ridala kaastöö lüroeepiliste regilaulude teadusliku väljaande koostamisel. Peale selle on neil rahvaluulet käsitlevaid artikleid ning rahvaluule-ülevaateid õpikutes ja kirjanduslugudes ning rahvaluuletekstide valikuid lugemikes. Kirjutisi rahvaluulest on ilmunud ka Suitsult. Nad ei olnud ju otseselt folkloristid, teatmeteosteski antud määratlused on kirjandusteadlane, keeleteadlane (Ridala puhul esineb küll ka veidi laiemalt mõistetav filoloog), ometi on rahvaluulel nende elutöös märkimisväärne osa. Eriti muidugi Aavikul ja Ridalal, juba ameti tõttu. Töötades aastaid õpetajatena, Ridala hiljem Helsingi ülikoolis lektorina ning pidades sinna juurde veel arvukalt ettekandeid, on nende eesti rahvaluulet tutvustav tegevus olnud väga ulatuslik. Tuglas ei ole küll folkloristikas ülikooliõpetust saanud, aga tema mõtted regilaulust on asjakohased ning on olnud mõnel puhul suunaandjakski. Tuglase rahvaluulet laiemalt puudutavates kirjutistes on originaalsust ja haaret väljapoole läänemeresoomelise areaali piire. Lisaks muule on nad oma õpikutes ja kirjanduslugudes rääkinud rahvaluule kogumisest, kogude sisukusest ja suurusest ning sellega süvendanud teadmist, et rahvaluulega oleme nii kvaliteedi kui ka kvantiteedi poolest maailmas hästi esindatud.

Rahvaluule on ju rahvakultuuri vaimse osa tähtsamaid komponente. Siinkäsitletud nooreestlaste puhul mingit rahvaluule halvakspidamist küll kuidagi ei oska märgata, ei Noor-Eesti organisatsioonina eksisteerimise ajal ega hiljem. Ja laiemaski plaanis - ega vastandumine ja ammugi mitte põlastamine ei olnud ju alguseski eesmärk, eesmärk oli eesti kirjanduse taseme tõstmine, vaatevälja avardamine, kultuurielu elavdamine. Kavandati kiireid teid edasiliikumiseks, selliselt, nagu tol ajajärgul asjakohane tundus, ja õnneks on Eesti ühiskonnas selliseks spurdiks alati potentsiaale leidunud. Oldi eestlased, oldi rahvuslased ja püüti oma tegevusega Eesti kultuuri väärtustada - see olekski vist asja lihtne tuum, vähemalt rahvaluule poolt vaadates. Ilmselt jäi Noor-Eesti alguse rahvuslik põhi püsima ka maailmavaatelisel kujunemisel läbi ajaloo keerdkäikude. Ja lugupidavat suhtumist meie esivanemate loomingusse võib näha ühe ühenduslülina kõnealuste nooreestlaste vahel kui ühist komponenti nende kultuurikäsituses. 


\section{Kommentaarid}

1 Johannes Aaviku päevikumõtteid on tutvustanud Helgi Vihma - vt Kultuurilugu kirjapeeglis. Johannes Aaviku \& Friedebert Tuglase kirjavahetus. Koostanud ja kommenteerinud Helgi Vihma. Tallinn, Valgus, 1990, lk 7-8. (Eesti Muinsuskaitse Selts.)

2 Annisti uurimus ilmus kolmes osas: I - Kalevipoeg eesti rahvaluules (Tartu, 1934); II "Kalevipoja” saamislugu (Tartu, 1936); III “Kalevipoeg” kui kunstiteos (Tartu, 1944); nüüdseks on teos ilmunud ka tervikuna, koos autori hilisemate paranduste ja täiendustega: August Annist, Friedrich Reinhold Kreutzwaldi "Kalevipoeg”. Toimetanud Ülo Tedre. Tallinn, Eesti Keele Sihtasutus, 2005 (Eesti Kirjandusmuuseum).

3 Oli ju teisigi regivärsilise lüroeepika loojaid. Siinse teemaga enim seotuna võib mainida Hella Wuolijoe Esimese maailmasõja puhkemisest ajendatud poeemi "Sõja laul" (H. Wuolijoki, Sõja laul. Tallinna Kaja, 1914, nr 18-19, lk 219-226), mis aktuaalse teema tõttu ilmus teist korda juba järgmisel aastal (H. Wuolijoki, Sõja laul. Kokku seatud Hurda vanavarakogudes leiduvate teisendite järgi. Tallinn, Kirjastuse-ühisus "Maa", 1915). Hella Wuolijoe mainimine siinkohal pole päris ilmaaegne. Kuigi teed hiljem lahknesid, oli iseseisva elu ja haridustee alguses palju ühist. Ka Hella Wuolijoki (snd Murrik) siirdus õppima Helsingi ülikooli selsamal ajal, 1904. aastal, ja samuti suure rahvuslasena, lähtekohana seesama rahvuslik Postimehe ringkond, soosijatena needsamad Jaan Tõnisson ning Aino ja Oskar Kallas, taskus Postimehe korrespondendikaart. Ka oli ta algul Noor-Eestiga seotud, tema väikseid kirjatöid ilmus Noor-Eesti esimeses ja teises albumis. Temagi asus Helsingi ülikoolis Kaarle Krohni juhendatuna õppima rahvaluulet (põhiainena). Huvitav saatus on pisipoeemil "Sõja laul": see oli viimane kirjanduslik töö, mille Wuolijoki kirjutas eesti keeles ja samuti viimane enne kuueteist aasta pikkust pausi, mil ta tegutses äri alal. Kuid hiljemgi jätkus keerulise elukäigu ja kommunistliku maailmavaatega draamakirjanikul eesti regilauludel põhinevale "Sõja laulule" tähelepanu ja ta püüdis seda laiemalt tutvustada - poeemist on olemas tõlked saksa, soome ja vene keelde.

\section{Kirjandus}

Aarma, Liivi 1990. Kirjaoskus Eestis 18. sajandi lõpust 1880. aastateni (nekrutinimekirjade andmeil). Tallinn: Eesti Teaduste Akadeemia \& Ajaloo Instituut.

Aavik, Johannes 1914. Eesti rahvusliku suurteose keel. Keelelise uuenduse kirjastik 1. Tartu: Reform.

Aavik, Johannes 1916. Kreutzwald-Aavik. Parandatud Kalevipoeg I. Keelelise uuenduse kirjastik 16. Tartu: Reform.

Aavik, Johannes 1919. Valik rahvalaule. Valind ja seletavate lisade ning sõnastikuga varustand Johannes Aavik. Keelelise uuenduse kirjastik 24. Tartu: Istandik.

Aavik, Johannes 1924. Rahvaluule käsitlus keskkoolis. Kasvatus 9, lk 259-265.

Aavik, Johannes 1925. Rahvalauluvärsi ja selle lugemise küsimus. Looming 1, lk 92-95.

Aavik, Johannes 1933. Kuidas suhtuda "Kalevipojale". "Kalevipoja” arvustus keelelises, värsitehnilises, stiililises ja sisulises suhtes. Tallinn \& Tartu: Istandik. 
Aavik, Johannes 1935. Eesti rahvalaule koolidele ja üldsusele. Täiendanud mag. L. Põdras. Tartu: Noor-Eesti.

Aavik, Johannes \& Mihkla, Karl \& Parlo, Olev \& Põdras, Lucie 1935. Rahvalaule ja "Kalevala" keskkoolidele. Lisaks kunstlüürikat. Tartu: Noor-Eesti Kirjastus.

Aavik, Johannes \& Parlo, Olev \& Mihkla, Karl 1944a. Eesti kirjanduslugu gümnaasiumile I. 3. klass. Tallinn: Eesti Kirjastus.

Aavik, Johannes \& Parlo, Olev \& Mihkla, Karl 1944b. Eesti kirjanduslugu 1. /Geislingen/, Eddy, 1944.

Aavik, Johannes \& Parlo, Olev \& Mihkla, Karl 1947. Eesti kirjanduslugu I. 2. osa: Romantismi ajastu lõpp. Stilistikat ja rahvalaule. Geislingen.

Aavik, Johannes 1970. Eesti rahvalaule. New York: Eesti Kultuurfondi Kirjastus.

Aavik, Johannes 1988. Üks meie kulturalise nõrkuse põhjustest: Vastupidine selektsioon. Aavik, Johannes. Rahvustunde nõrkusest Eestis. Eri aegade kirjutisi. Loomingu Raamatukogu 50. Tallinn: Perioodika.

Aavik, Johannes 1990 = Vihma, Helgi (koost ja komment). Kultuurilugu kirjapeeglis. Johannes Aaviku \& Friedebert Tuglase kirjavahetus. Tallinn: Valgus.

Annist, August 2005. Sissejuhatus. August Annist. Friedrich Reinhold Kreutzwaldi "Kalevipoeg". Tallinn: Eesti Keele Sihtasutus.

Grünthal, Riho 2005. Villem Grünthal-Ridala - keeleõpetaja ja kultuuri tutvustaja. Helsingi ülikooli eesti keele lektori tegevus maailmasõdade vahel. Olesk, Sirje (koost). Kultuurisild üle Soome lahe. Eesti - Soome akadeemilised ja kultuurisuhted 1918-1944. Tartu: Eesti Kirjandusmuuseum, lk 251-277.

Grünthal, Villem 1912. Eesti rahvaluule. Eesti Kirjandus, lk 395-403, 484-511.

Grünthal, Villem 1931 = V. Ridala-Grünthal. Eesti rahvaluule keelest. Eesti Kirjandus 5, lk 266-286.

Grünthal, Villem 1933 = W. Grünthal. Virolaisen kansanrunouden kuvaannollisista kertosanoista. Suomi V: 16. Helsinki, lk 102-119.

Hennoste, Tiit 2008. Noor-Eesti enesekoloniseerimisprojekt. Teine osa: Olulised kirjandusmõtteviisid ja nende suhted kolonialismiga 20. sajandi algupoole eesti kirjanduses. Methis 1/2, lk 262-275.

Järv, Ants 1992. Friedebert Tuglas ja rahvaluule. Eesti rahvaluule käsitlusi. Töid eesti filoloogia alalt. Tartu Ülikooli toimetised 943. Tartu, lk 99-108.

Kallas, Aino 1921. Noor-Eesti. Näopildid ja sihtjooned. Tartu: Noor-Eesti Kirjastus.

Kivimäe, Jüri 2008. Noor-Eesti tähendust otsides: vanu ja uusi mõtteid. Methis $1 / 2$, lk 21-43.

Kõressaar, Viktor 1970. Eessõna kolmandale trükile. Johannes Aavik. Eesti rahvalaule. New York: Eesti Kultuurfondi Kirjastus, lk 7-10.

Laugaste, Eduard 1992. Gustav Suitsu sidemetest rahvaluulega. Eesti rahvaluule käsitlusi. Töid eesti filoloogia alalt. Tartu Ülikooli toimetised 943. Tartu, lk 109-126. 
Loorits, Oskar 1955. Nelja sugupõlve saatustragöödia. Loorits, Oskar. Eesti ajaloo põhiprobleemid. Iseseisvuslaste kirjavara 11. Stockholm: Tõrvik, lk 121.

Mihkelson, Friedebert 1908. Põrgu väravas. Parallelid. Eesti Kirjandus 6-11, lk 224-232, 258-270, 301-307, 325-331, 352-361, 387-392.

Mirov, Ruth 2002. Eepose-igatsus. Lisandusi kirjanduse ja rahvaluule suhete probleemile. Mirov, Ruth. Sõnast sõnasse. Valik artikleid ja retsensioone. Tallinn \& Tartu: Eesti Keele Sihtasutus \& Eesti Kirjandusmuuseum, lk 447-470.

Mirov, Ruth 2005. Villem Grünthal-Ridala elust ja tööst. Villem Ridala. Püha Rist. Tallinn: Eesti Kirikute Nõukogu, lk 425-438.

Mirov, Ruth 2006. "Kalevipoja" parandamisest ja Ridala ümberluulendusest. Looming 4 , lk 569-578.

Mirov, Ruth 2007. Kirjamehed ja “Nurganaine”. Looming 12, lk 1861-1875.

Niinivaara, Eeva 1981. Villem Ridalan folkloristiset balladit. Kasvumaa. Eeva Niinivaaran kirjoituksia vuosilta 1923-1981. Helsinki: Helsingin yliopisto, lk 220-229.

Olesk, Sirje \& Laak, Marin 2008. Noor-Eesti rollist eesti kirjandus- ja kultuuriloos. Methis $1 / 2$, lk 7 .

Ridala, Villem 1918. +++. Kümme aastat. Noor-Eesti 1905-1915. Tartu: Osaühisus NoorEesti Kirjastus, lk 81-85.

Ridala, Villem (koost) 1919. Valik Eesti rahvalaulusid. Eesti Kirjanduse Seltsi Koolikirjanduse toimekond. Nooresoo kirjavara. 49. Tartu: Noor-Eesti Kirjastus.

Ridala, Villem 1921. Kalevipoeg [proosaümberjutustus]. Kirjutanud V. Ridala. Tallinn: Kool.

Ridala, Villem 1922. Eesti kirjanduse ajalugu koolidele I. Tartu: Noor-Eesti Kirjastus. Ridala, Villem 1924. Eesti kirjanduse ajalugu koolidele I. Tartu: Noor-Eesti Kirjastus. Ridala, Villem 1929. Kalevipoeg. Helsingi: Otava.

Ridala, Villem 2005. Püha Rist. Tallinn: Eesti Kirikute Nõukogu.

Ridala, Villem 1931 = V. Ridala-Grünthal. Eesti rahvaluule keelest. Eesti Kirjandus 5, lk 266-286.

Suits, Gustav 1906. Kaks ilmavaadet. Sihid ja vaated. Helsingi: Yrjö Weilin, lk 51-55.

Suits, Gustav 1907. Dr. Jakob Hurt. 10. VII 1839 - 31. XII 1906. In Memoriam. Sõnumed 5, 7, 8 (9., 11. ja 12. jaanuar).

Suits, Gustav 1911. "Kalevipoeg” rahvaeeposena ja kunstitööna. Eesti Kirjandus 11/12, lk 449-461.

Suits, Gustav 1919. Eesti lugemiseraamat. Valitud lugemispalad Eesti kirjanduse arenemise teelt II. Helsingi: Otava.

Suits, Gustav 1931. Noor-Eesti nõlvakult. Kahe revolutsiooni vahel. Tartu: Noor-Eesti. 
Suits, Gustav 1953. Eesti kirjanduslugu I. Algusest kuni ärkamisaja lõpuni. Lund: Eesti Kirjanike Kooperatiiv. Uustrükk koos lisandustega 1999: Eesti kirjanduslugu. Eesti mõttelugu 25.Tartu: Ilmamaa.

Suitsmaa 1924. Meie rahvalaulu skandeerimine. Looming 7, lk 538-542.

Suitsmaa 1925. Skandeerimise poolt ja vastu. Looming 3, lk 268-270.

Särg, Taive 2004. Regilaulu skandeeriv esitus kui vältelise meetrumi manifestatsioon: Johannes Aaviku vaated. Vihma, Helgi (koost). Artikleid ja arhivaale. Keeleuuenduse kirjastik B:5. Tallinn: Johannes Aaviku Selts, lk 93-113.

Talve, Ilmar 1953. Noor Gustav Suits Soomes 1901-1911. Kultuuriajaloolisi äärjooni. Tulimuld 6, lk 337-359.

Tuglas, Friedebert 1934. Lühike Eesti kirjanduslugu. Elav teadus 25. Tartu: Eesti Kirjanduse Selts.

Tuglas, Friedebert 1939. Viron kirjallisuuden historia. Helsinki: Otava.

Tuglas, Friedebert 1996a. Gustav Suits Noor-Eesti algajul. Mälestusi G. Suitsu viiekümnenda sünnipäeva puhul. Tuglas, Friedebert. Kogutud teosed 7. Kriitika I. Kriitika II. Tallinn: Underi ja Tuglase Kirjanduskeskus, lk 318-327.

Tuglas, Friedebert 1996b. Kirjanduslik stiil. Lehekülgi Eesti salmi ja proosa ajaloost. Tuglas, Friedebert. Kogutud teosed 7. Kriitika I. Kriitika II. Tallinn: Underi ja Tuglase Kirjanduskeskus, lk 413-457.

Tuglas, Friedebert 1996c. "Kalevipoeg". Mõtteid teose parandamise puhul. Tuglas, Friedebert. Kogutud teosed 7. Kriitika I. Kriitika II. Tallinn: Underi ja Tuglase Kirjanduskeskus, lk 80-97.

Tuglas, Friedebert 2001. Rahvuslik kirjandus. Kõne, peetud Eesti Kirjanduse Seltsi aastakoosolekul 29. aprillil ja Tallinna Töölisteatris 4. mail 1934. Tuglas, Friedebert. Kogutud teosed 9. Kriitika V. Kriitika VI. Tallinn: Underi ja Tuglase Kirjanduskeskus, lk 270-286.

Tuglas, Friedebert 2004. Paljastamiskirg. Tuglas, Friedebert. Kogutud teosed 10. Kriitika VII. Kriitika VIII. Tallinn: Underi ja Tuglase Kirjanduskeskus, lk 177-182.

Undusk, Jaan 1990. Kalevipoeg ja Prometheus. Friedebert Tuglase "Põrgu väravas” ja selle koht rahvaluuleteaduses. Keel ja Kirjandus 10-12, lk 587-597, 645-656, 720-735.

Vihma, Helgi (koost \& komment) 1990. Kultuurilugu kirjapeeglis. Johannes Aaviku \& Friedebert Tuglase kirjavahetus. Tallinn: Valgus. 


\title{
Summary
}

\section{Noor-Eesti and folklore}

\author{
Ruth Mirov
}

Key words: Johannes Aavik, Villem Grünthal-Ridala, Gustav Suits, Friedebert Tuglas, Noor-Eesti, Kalevipoeg, relations between literature and folklore, runic song

The Noor-Eesti (Young Estonia) group, which gradually developed into a literary-cultural movement, was initiated by Gustav Suits in the early 20 th century. Being a gymnasium student at the time, he gathered around himself active nationally-minded young people, some of whom later on became renowned scientists and writers - apart from Suits himself, Friedebert Tuglas, Johannes Aavik and Villem Grünthal-Ridala. In 1905 and 1906 Suits, Aavik and Grünthal-Ridala left for Helsinki to study at university. Besides other courses, they also attended lectures on folkloristics. The young men were supported in their endeavours to study national sciences by Jaan Tõnisson, Chief Editor of the newspaper Postimees (Postman) published in Tartu, as well as Aino and Oskar Kallas, the latter of whom had received his $\mathrm{PhD}$ degree in folkloristics at Helsinki University in 1901. Friedebert Tuglas, due to his revolutionary activities, did not complete his studies at university; yet, in 1906 he also left for Finland - as an exile.

Folklore achieved a high status in Estonian cultural life from the mid-19th century, in the period of National Awakening, when Friedrich Reinhold Kreutzwald published the national epic Kalevipoeg (Kalev's Son) and Jakob Hurt started to organise the collection of folklore under the auspices of the Society of Estonian Literati. In 1888 Jakob Hurt initiated extensive collection of folklore through the correspondents' network, which in the Russification campaign of the last decades of the 19th century became the only nationwide undertaking. Concurrently with Hurt, Matthias Johann Eisen took up folklore collection, and in 1904 Oskar Kallas initiated an extensive campaign for collecting folk music. Due to all this, by the time of the foundation of the Noor-Eesti literary group, folklore had been established in the public mind for nearly half a century and was recognised, especially by the intelligentsia, as one of the pillars of national identity. Therefore it is understandable that the members of the Noor-Eesti group were eager to be academically trained in the field of folklore and that folklore and especially the runic song acquired an important role in their lifework. However, in addition to their literary creation and literary and linguistic studies, their activity related to folklore has not evoked any wider response.

This article provides an overview of the folkloristic activities of the aforementioned four penmen from the Noor-Eesti literary group, introducing the corresponding articles, collections of texts, etc. In the case of Aavik and Ridala the role of folklore in their educational work is also worth mentioning. Besides, the article discusses literary creation based on folklore, in which Ridala was especially prolific, being represented by three voluminous rune poems and a collection of ballads. As they were educated in Finland, their ideal was the Finnish national epic Kalevala, which was based on folk songs, and the form inherent in the Finnish old folk song - the so-called Kalevala verse. They also appreciated highly the Estonian runic verse folk song, which employs the same form 
principle. The runic song was treated by them as artistically high-level poetry. Proceeding from these stances, they (especially Aavik and Tuglas) criticised the Estonian national epic Kalevipoeg, whereas Aavik and Ridala made attempts to re-versify the epic in an ideal, regulated runic verse form. 